\title{
Evaluation from otolith Sr stable isotope ratios of possible juvenile growth areas of Japanese eels collected from the West Mariana Ridge spawning area
}

\author{
Tsuguo Otake ${ }^{1,7} \cdot$ Yosuke Amano $^{1,8} \cdot$ Kotaro Shirai $^{1} \cdot$ Noritaka Mochioka $^{2} \cdot$ Toshiro Takahashi $^{3,9} \cdot$ Seinen Chow $^{4}$. \\ Hiroaki Kurogi ${ }^{5}$. Shouzeng Dou $^{6} \cdot$ Asuka Yamaguchi $^{1} \cdot$ Katsumi Tsukamoto $^{1,10}$
}

Received: 10 October 2018 / Accepted: 17 February 2019 / Published online: 13 March 2019

(c) The Author(s) 2019

\begin{abstract}
The widely distributed East Asian Japanese eel Anguilla japonica constitutes a single genetically homogeneous population with a single spawning area near the West Mariana Ridge. Otolith ${ }^{87} \mathrm{Sr} /{ }^{86} \mathrm{Sr}$ ratios of adults (categorized as "river", "estuarine" or "sea" eels, according to their habitat use history determined from otolith Sr:Ca ratio analysis) collected from the spawning area in 2008 and 2009 were examined in an attempt to determine their juvenile growth areas. In addition, ${ }^{87} \mathrm{Sr} /{ }^{86} \mathrm{Sr}$ ratios of water samples from rivers in China, Taiwan, Korea, and Japan were determined. Otolith ${ }^{87} \mathrm{Sr} /{ }^{86} \mathrm{Sr}$ ratios of the "river", "estuarine" and "sea" eels were 0.707793, 0.708580-0.709944 and 0.709068, respectively, and water sample ratios from China, Korea, Taiwan, and Japan were 0.7104320-0.7141010, 0.7190826-0.7227976, 0.7115523-0.7146914 and 0.706191-0.712484, respectively. "River" and "estuarine" eels, which had otolith ${ }^{87} \mathrm{Sr} /{ }^{86} \mathrm{Sr}$ ratios less than 0.7092 (seawater ratio), appeared to have inhabited Japanese rivers and/or estuaries because similarly low isotope ratios were recorded only from Japan. However, the juvenile growth areas of other eels were unknown, as their origins could not be determined from otolith ${ }^{87} \mathrm{Sr} /{ }^{86} \mathrm{Sr}$ ratios alone, and required further information regarding otolith elemental and isotope compositions.
\end{abstract}

Keywords Anguilla japonica $\cdot$ Japanese eel $\cdot$ Juvenile growth area $\cdot$ Otolith ${ }^{87} \mathrm{Sr} /{ }^{86} \mathrm{Sr}$ ratio

Tsuguo Otake

otake@aqua.fs.a.u-tokyo.ac.jp

1 Atmosphere and Ocean Research Institute, The University of Tokyo, 5-1-5 Kashiwanoha, Kashiwa, Chiba 277-8564, Japan

2 Faculty of Agriculture, Kyushu University, 6-10-1 Hakozaki, Higashi-ku, Fukuoka 812-8581, Japan

3 Institute for Research on Earth Evolution, Japan Agency for Marine-Earth Science and Technology (JAMSTEC), 2-15 Natsushima, Yokosuka, Kanagawa 237-0061, Japan

4 National Research Institute of Fisheries Science, Japan Fisheries Research and Education Agency, 2-12-4 Fukuura, Kanazawa-ku, Yokohama, Kanagawa 236-8648, Japan

5 Yokosuka Laboratory, National Research Institute of Fisheries Science, Japan Fisheries Research and Education Agency, 6-31-1 Nagai, Yokosuka, Kanagawa 238-0316, Japan
6 CAS Key Laboratory of Marine Ecology and Environmental Sciences, Institute of Oceanology, Chinese Academy of Sciences, Qingdao 266071, People's Republic of China

7 Present Address: Graduate School of Agriculture and Life Sciences, The University of Tokyo, 1-1-1 Yayoi, Bunkyo-ku, Tokyo 113-8654, Japan

8 Present Address: Fukushima Prefectural Fisheries and Marine Science Research Centre, 13-2 Onahamashimokajiro, Iwaki, Fukushima 971-0316, Japan

9 Present Address: Faculty of Science, Niigata University, 8050 Ikarashi, Nishi-ku, Niigata 950-2181, Japan

10 Present Address: College of Bioresouce Sciences, Nihon University, 1866 Kameino, Fujisawa, Kanagawa 252-0880, Japan 


\section{Introduction}

The Japanese eel Anguilla japonica is a catadromous temperate species and a high value commercial fisheries target in East Asia. However, stock levels of Japanese eels associated with glass eel recruitment have shown serious declines throughout the distribution range in recent decades, as have those of two other Northern Hemisphere temperate eel species, the European eel A. anguilla and American eel A. rostrata. The 2010 catch of exploitable stock of Japanese eels and glass eels in Japan has been estimated as only $8 \%$ of maximum post-World War II catch levels (Tanaka 2014), with continued the downward trend thereafter. The European eel is listed as critically endangered on the IUCN Red List (2011 Version), and both Japanese and American eels were considered as "threatened" in 2014 by the IUCN (Japanese eel: Jacoby and Gollock 2014; American eel: Jacoby et al. 2014). Such a remarkable decline of eel stocks in the Northern Hemisphere is thought to have been caused by various anthropogenic factors, including overexploitation of stock, habitat loss due to construction of dams, weirs, sluices and culverts, pollution and disease, as well as by environmental factors, such as changes in climatic and oceanic current conditions, that are detrimental to larval recruitment (Feunteun 2002; Tatsukawa 2003; Dekker 2003; Kimura and Tsukamoto 2006; Kim et al. 2007; Friedland et al. 2007; Bonhommeau et al. 2008; Miller et al. 2009; Tsukamoto et al. 2009; Itakura et al. 2014; Yokouchi et al. 2014; Chang et al. 2015). The critical status of those eel populations has accelerated attempts to manage and restore them, involving studies on life history, including spawning and oceanic migration of larvae and maturing adults, habitat use and behavior ("yellow eel" stage) (Feunteun 2002), as well as artificial seedling production.

Spawning-condition adults and fertilized eggs of Japanese eels were first collected from waters along the seamount chain near the Mariana Trench in 2008 and 2009 (Chow et al. 2009; Tsukamoto et al. 2011; Kurogi et al. 2011), additional eggs being collected a few years later (Aoyama et al. 2014). This spawning location discovery provided definitive evidence for a single spawning area for the species, otherwise occurring over a broad area of East Asia, including northern Luzon (Philippines), Taiwan, eastern China, Korea, and Japan. It was also confirmed that Japanese eels constitute a single panmictic population, as indicated by mitochondrial and microsatellite DNA studies (Ishikawa et al. 2001; Tseng et al. 2001; Han et al. 2010a, Minegishi et al. 2012; Gong et al. 2014). However, even though the geographically broad range is supported by a single spawning area well distant from juvenile growth areas, it is possible that some East Asian regions may be more important than others in contributing adult fish to the reproduction pool year by year. If so, intensive management and restoration activities targeting such juvenile growth areas would be the most effective means of working towards restoration of the species. However, to date nothing is known regarding which juvenile growth areas contribute adult fish to the spawning population.

Recent studies using pop-up archival tags on "silver eel" stage individuals have accumulated useful information on spawning migration routes and behaviors of several anguillid eel species (Jellyman and Tsukamoto 2002, 2005, 2010; Manabe et al. 2011; Aarestrup et al. 2009; Chow et al. 2015; Righton et al. 2016; Schabetsberger et al. 2015). BeguerPon et al. (2015) successfully tracked the movements of one maturing American eel, equipped with pop-up satellite archival tags, from the Scotian Shelf into the northern limit of the Sargasso Sea spawning area, although most other tracked eels have not reached close to their spawning areas. The aforementioned study demonstrated that rivers and/or estuaries around the Scotian Shelf represented a juvenile growth area of American eel that contributed to spawning area stock. Although Manabe et al. (2011) tracked "silver eel" stage A. japonica individuals released near Japan using pop-up tags, the eels neither reached the spawning area nor showed evidence of spawning related behaviors. A modelling simulation study by Chang et al. (2016) suggested that ocean circulation significantly affected the spawning migration route and duration of Japanese eels after their departure from the south coast of Japan.

Isotopic and elemental compositions of fish otoliths are also known to be useful as a natural fingerprint of historical environments in studies of movement ecology (Thorrold et al. 2001; Rooker et al. 2008, 2014; Walther et al. 2011; Walther and Limburg 2012; Molly et al. 2015). In particular, otolith strontium stable isotopic ratios $\left({ }^{87} \mathrm{Sr} /{ }^{86} \mathrm{Sr}\right.$ ratio) of freshwater fishes have been clearly shown to indicate the water characteristics of habitats occupied by the fishes. Otolith ${ }^{87} \mathrm{Sr} /{ }^{86} \mathrm{Sr}$ ratios vary in direct proportion to the ratio of ambient water, which reflects the ratio of the watershed geology, such as age and composition of rock formations (Kennedy et al. 1997, 2000, 2002; Barnett-Johnson et al. 2005; Sano et al. 2008; Hobbs et al. 2010; Amakawa et al. 2012; Garcez et al. 2015). Therefore, a marked geological diversity across a study area, being reflected in otolith ${ }^{87} \mathrm{Sr} /{ }^{86} \mathrm{Sr}$ ratios of fishes distributed in the area, can be expected to vary significantly among habitat tributaries. Previously inhabited tributaries of each fish can be reconstructed from the otolith ${ }^{87} \mathrm{Sr} /{ }^{86} \mathrm{Sr}$ ratio and bedrock geology.

In the present study, we attempted to identify the juvenile growth areas of spawning-condition Japanese eels collected from the spawning area along the seamount chain of the West Mariana Ridge in 2008 and 2009, based on their otolith ${ }^{87} \mathrm{Sr} /{ }^{86} \mathrm{Sr}$ ratios. Thirty-three water samples from 
representative rivers within the distribution range of the species (six rivers in China, five in Korea, four in Taiwan, and 18 in Japan) were also used for ${ }^{87} \mathrm{Sr} /{ }^{86} \mathrm{Sr}$ ratio analysis, to provide insight into the underlying lithology of juvenile Japanese eel growth areas in combination with literature values. This should provide some initial information on the contribution of adult Japanese eels from East Asian regions to the spawning population and aid the establishment of more effective management and restoration strategies for this commercially important fish.

\section{Materials and methods}

\section{Fish sample collection}

Twelve spawning-condition adult $A$. japonica were collected from the spawning area during R/V Kaiyo Maru (Fisheries Agency, Japan) and Hokko Maru (Fisheries Agency, Japan) cruises conducted from May to August (2008) and in May and June (2009) (Chow et al. 2009; Tsukamoto et al. 2011; Kurogi et al. 2011), captured in a large midwater trawl net [maximum mouth opening $60 \mathrm{~m}$ wide and $50 \mathrm{~m}$ high, with $7 \mathrm{~mm}$ mesh cod end and a graded series of mesh sizes (60-2010 $\mathrm{mm}$ ) in the main body of the net] towed along the southern part of the West Mariana Ridge. Collection details and biological data for each fish were given by Chow et al. (2009), Kurogi et al. (2011) and Tsukamoto et al. (2011). Juvenile stage ("yellow eel") Japanese eels, known to reside not only in freshwater, but also in brackish estuarine and coastal marine habitats, can be divided into three categories based on their otolith $\mathrm{Sr}$ :Ca ratios according to their history of freshwater, estuarine and seawater habitat use (Tsukamoto et al. 1998; Tzeng et al. 2000; Tsukamoto and Arai 2001), viz "river" eels-individuals that entered and remained in freshwater river habitats after arrival of the glass eel stage in an estuary; "estuarine" eels-individuals inhabiting estuaries or moving between different habitats; and "sea" eels-individuals that at no time entered freshwater. The
12 spawning-condition adult eels comprised one "river" eel, six "estuarine" eels and five "sea" eels based on otolith Sr:Ca ratio analysis by Mochioka et al. (2010). Since the ${ }^{87} \mathrm{Sr} /{ }^{86} \mathrm{Sr}$ ratio of seawater is consistently 0.7092 (Goldstein and Jacobsen 1987; McArthur 1994), with the ratios of "sea" eel otoliths expected to be of similar value and unchangeable among different seawater habitats, four of the five "sea" eels were excluded from the otolith ${ }^{87} \mathrm{Sr} /{ }^{86} \mathrm{Sr}$ ratio analysis. Thus, seven of the 12 spawning-condition adult eels (one "river", five "estuarine", and one "sea" eel, Table 1) were used for the analysis in the present study.

\section{River water sample collection}

River water samples were taken during 2008 and 2011 from 33 rivers-in mainland China (6), South-Korea (5), Taiwan (4) and Japan (18) (Fig. 1, Table 2), all known habitats of Japanese eel. One-liter water samples from the lowest freshwater reach of each river were filtered through a 0.45$\mu \mathrm{m}$ membrane filter (ADVANTEC, Tokyo, Japan) soon after sampling, and then acidified (1\%) using concentrated ultrapure $\mathrm{HCl}$ (Tamapure-AA-100, Tama Chemicals, Tokyo, Japan) and stored in acid-washed polypropylene bottles. All glass filtration materials and sampling bottles were acidwashed prior to use.

\section{${ }^{87} \mathrm{Sr} /{ }^{86} \mathrm{Sr}$ ratio analysis of otolith}

Otoliths removed from each fish were embedded in epoxy resin (Epofix; Struers, Denmark), mounted on a glass slide, and ground using a grinding machine equipped with $70 \mu \mathrm{m}$ and $13 \mu \mathrm{m}$ diamond cup-wheels (Diskoplan-TS; Struers, Denmark), so as to expose the elver mark (a marked ring formed at the time of completion of metamorphosis from the leptocephalus to glass eel stage). A sample of otolith material for analysis was taken from outside a $150 \mu \mathrm{m}$ radius from the otolith core using a micromilling technique using a MicroMill (New Wave Research Inc., USA) (Fig. 2). The otolith central portion (less than $150 \mu \mathrm{m}$ from the core),

Table 1 Sex and total length of spawning-condition adult eels, collection data and location, and otolith ${ }^{87} \mathrm{Sr} /{ }^{86} \mathrm{Sr}$ ratios

\begin{tabular}{|c|c|c|c|c|c|c|c|}
\hline \multirow[t]{2}{*}{ Fish no. } & \multirow[t]{2}{*}{ Sex } & \multirow{2}{*}{$\begin{array}{l}\text { Total length } \\
(\mathrm{mm})\end{array}$} & \multirow[t]{2}{*}{ Sampling date } & \multicolumn{2}{|l|}{ Locatity } & \multirow[t]{2}{*}{ Life history category } & \multirow[t]{2}{*}{ Otolith ${ }^{87} \mathrm{Sr} /{ }^{86} \mathrm{Sr}$ ratio ${ }^{\mathrm{a}}$} \\
\hline & & & & Latitude (N) & Longitude (E) & & \\
\hline E16-2 & Male & 485 & 3 Jun 2008 & $13-00.70$ & $142-17.57$ & River eel & $0.707793 \pm 0.000014$ \\
\hline E18-1 & Male & 515 & 4 Jun 2008 & $13-02.62$ & $142-13.27$ & Estuarine eel & $0.709404 \pm 0.000011$ \\
\hline U8-1 & Female & 555 & 31 Aug 2008 & $14-06.69$ & $142-44.04$ & Estuarine eel & $0.708580 \pm 0.000010$ \\
\hline U8-2 & Female & 662 & 31 Aug 2008 & $14-06.69$ & $142-44.04$ & Sea eel & $0.709068 \pm 0.000010$ \\
\hline M-1 & Male & 639 & 19 Jun 2009 & $12-21.82$ & $141-22.84$ & Estuarine eel & $0.709231 \pm 0.000011$ \\
\hline EH13-1 & Male & 585 & 21 Jun 2009 & $12-19.95$ & $141-13.10$ & Estuarine eel & $0.709928 \pm 0.000008$ \\
\hline M-3 & Male & 447 & 22 Jun 2009 & $12-18.85$ & $141-33.47$ & Estuarine eel & $0.709935 \pm 0.000001$ \\
\hline
\end{tabular}

${ }^{\mathrm{a}}$ Errors are assigned from internal precision (2SE) 
Fig. 1 Map of East Asia showing the rivers from which water samples were taken. River numbers correspond to those listed in Table 2. Bold gray coastlines indicate recruitment areas of Japanese eel

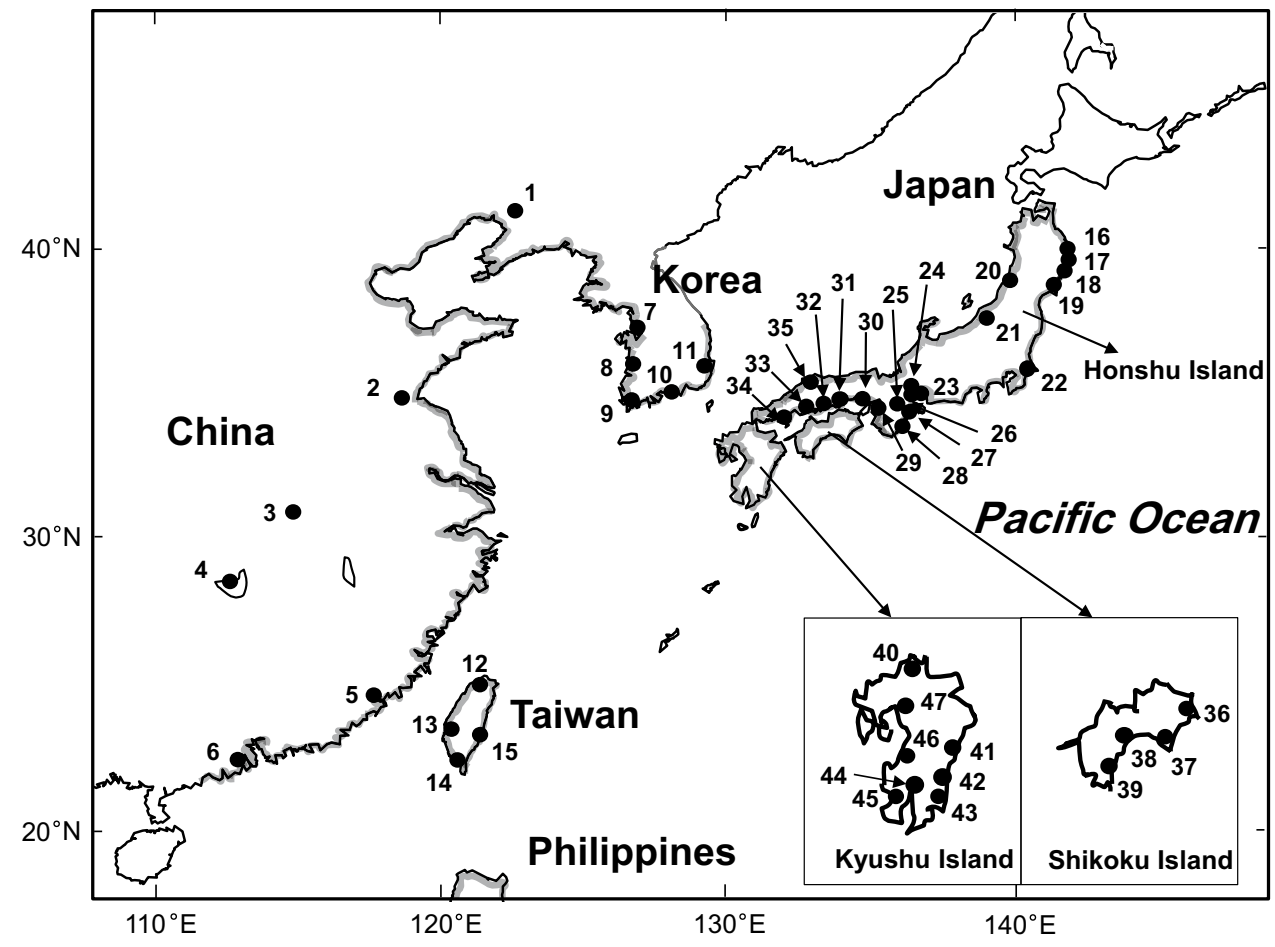

which corresponded to the sea-going leptocephalus stage, had been previously removed by drilling to avoid contamination. Micromilled samples were not taken from the outermost portion of the otolith (corresponding to the oceanic migration period during the silver eel stage), the otolith portion representing that developmental period likely being narrow since no feeding (and hence no body growth) would have occurred during oceanic migration (Chow et al. 2010; Kurogi et al. 2011).

Micromilling, chemical separation and thermal-ionization mass spectrometry (TIMS) for ${ }^{87} \mathrm{Sr} /{ }^{86} \mathrm{Sr}$ analysis were performed following Takahashi et al. (2006, 2009). Each otolith was placed on the stage of the micromilling machine, and a single drop of Milli-Q water put on the subsequently drilled sampling point. The diameter and depth of each drill hole were approximately $270 \mu \mathrm{m}$ and $45 \mu \mathrm{m}$, respectively, two points sampled on each otolith (Fig. 2). The drilled sample slurry was then pipetted from the otolith surface and transferred to a cleaned PFA screw-cap vial. The PFA vial was heated to evaporate water, and $7 \mathrm{M} \mathrm{HNO}_{3}$ (TamapureAA-100, Tama Chemicals, Tokyo, Japan) added to dissolve the otolith sample. Sr was subsequently extracted and purified from the resulting solution by ion chromatography using Sr Spec resin (Eichrom Technologies Inc., USA). ${ }^{87} \mathrm{Sr} /{ }^{86} \mathrm{Sr}$ analysis was conducted on a TIMS (TRITON TI, Thermo Finnegan, USA), installed at the Japan Agency for MarineEarth Science and Technology (JAMSTEC), Japan. Each ${ }^{87} \mathrm{Sr} /{ }^{86} \mathrm{Sr}$ ratio datum was normalized for isotopic fractionation using a correction value for ${ }^{88} \mathrm{Sr} /{ }^{86} \mathrm{Sr}$ of 8.375209 . The
NIST SRM 987 standard value of $0.710253 \pm 0.000011(2 \sigma$, $n=16$ ) was corrected for instrumental drift and bias using a correction to the NIST SRM 987 standard of 0.710245 for each daily data set.

\section{${ }^{87} \mathrm{Sr} /{ }^{86} \mathrm{Sr}$ ratio analysis of river water}

From each water sample, $980 \mathrm{ml}$ was evaporated in a Teflon bottle on a hot plate at $90{ }^{\circ} \mathrm{C}$, and the residue then dissolved with $0.5 \mathrm{~mL}$ of $7 \mathrm{M} \mathrm{HNO}_{3}$ (Tamapure-AA-100, Tama Chemicals, Tokyo, Japan). Chemical separation and mass spectrometry for Sr were performed using the same protocols as for the otolith samples. During water sample measurement, the NIST SRM 987 value was $0.710245 \pm 0.000014$ $(2 \sigma, n=16)$.

\section{Results}

The otolith ${ }^{87} \mathrm{Sr} /{ }^{86} \mathrm{Sr}$ ratio of the "river" eel (no. E16-2) from the spawning area was 0.707793 , those of five "estuarine" eels (no. E18-1, U8-1, M-1, EH13-1, M-3) ranging from 0.708580 to 0.709944 (mean \pm SD: $0.709416 \pm 0.000562)$ (Table 1, Fig. 3). The "sea" eel (no. U8-2) otolith showed a ratio of 0.709068 , a little lower than the sea water ratio (0.7092, Goldstein and Jacobsen 1987; McArthur 1994). Table 2 shows water ${ }^{87} \mathrm{Sr} /{ }^{86} \mathrm{Sr}$ ratios of East Asian rivers, including ratios of 14 Japanese rivers given by Yamanaka et al. (2005), Amakawa et al. (2012) and Amano et al. (2013). Water ${ }^{87} \mathrm{Sr} /{ }^{86} \mathrm{Sr}$ ratios 
Table $2{ }^{87} \mathrm{Sr} /{ }^{86} \mathrm{Sr}$ ratios of water samples from Chinese, Korean, Taiwanese and Japanese rivers, including data from previous studies

\begin{tabular}{|c|c|c|c|c|}
\hline Name of river & $\begin{array}{l}\text { Location } \\
\text { no. in Fig. } 1\end{array}$ & Sampling year & ${ }^{87} \mathrm{Sr} /{ }^{86} \mathrm{Sr}$ ratio & Reference \\
\hline \multicolumn{5}{|l|}{ China } \\
\hline Daliaohe R. & 1 & 2008 & 0.714101 & \\
\hline Qingkouhe R. & 2 & 2008 & 0.711373 & \\
\hline Yangtze R. & 3 & 2008 & 0.710432 & \\
\hline Dongting Lake & 4 & 2008 & 0.710570 & \\
\hline Jiulongjiang R. & 5 & 2008 & 0.712474 & \\
\hline Pear R. & 6 & 2008 & 0.711275 & \\
\hline \multicolumn{5}{|l|}{ Korea } \\
\hline Han-gang & 7 & 2008 & 0.722798 & \\
\hline Geum-gang & 8 & 2008 & 0.719854 & \\
\hline Yeongsan-gang & 9 & 2008 & 0.716200 & \\
\hline Seoumjin-gang & 10 & 2008 & 0.713016 & \\
\hline Nakdong-gang & 11 & 2008 & 0.713083 & \\
\hline \multicolumn{5}{|l|}{ Taiwan } \\
\hline Danshi R. & 12 & 2008 & 0.711552 & \\
\hline Dajia R. & 13 & 2008 & 0.714017 & \\
\hline Gaoping R. & 14 & 2008 & 0.712505 & \\
\hline Beinan R. & 15 & 2008 & 0.714691 & \\
\hline \multicolumn{5}{|l|}{ Japan } \\
\hline \multicolumn{5}{|c|}{ North-eastern region of Honshu Island } \\
\hline Hei R. & 16 & 2005 & 0.707610 & Amakawa et al. (2012) \\
\hline Otsuchi R. & 17 & 2006 & 0.708434 & Amakawa et al. (2012) \\
\hline Unosumai R. & 18 & 2005,2006 & $0.706151 \pm 0.000169^{\mathrm{a}}$ & Amakawa et al. (2012) \\
\hline Kitakami R. & 19 & 1985 & 0.7063 & $\begin{array}{l}\text { Goldstein and Jacobsen } \\
\text { (1987) }\end{array}$ \\
\hline Mogami R. & 20 & 1985 & 0.7071 & $\begin{array}{l}\text { Goldstein and Jacobsen } \\
\text { (1987) }\end{array}$ \\
\hline Shinano R. & 21 & 1985 & 0.7083 & $\begin{array}{l}\text { Goldstein and Jacobsen } \\
\text { (1987) }\end{array}$ \\
\hline Tone R. & 22 & 1985 & 0.7083 & $\begin{array}{l}\text { Goldstein and Jacobsen } \\
\text { (1987) }\end{array}$ \\
\hline \multicolumn{5}{|c|}{ Central region of Honshu Island } \\
\hline Nagara R. & 23 & 2005,2006, 2007 & $0.712469 \pm 0.000415^{\mathrm{a}}$ & Amakawa et al. (2012) \\
\hline Kiso R. & 24 & 2010 & 0.711085 & Amakawa et al. (2012) \\
\hline Ibi R. & 25 & 2010 & 0.713091 & Amakawa et al. (2012) \\
\hline Suzuka R. & 26 & 2010 & 0.711097 & Amakawa et al. (2012) \\
\hline Kushida R. & 27 & 2005,2006 & $0.709110 \pm 0.000675^{\mathrm{a}}$ & Amakawa et al. (2012) \\
\hline Miya R. & 28 & 2005,2006 & $0.709557 \pm 0.000273^{\mathrm{a}}$ & Amakawa et al. (2012) \\
\hline Yodo R. & 29 & 1992 1999 & 0.71146 & Yamanaka et al. (2005) \\
\hline Kako R. & 30 & 2011 & 0.708809 & \\
\hline \multicolumn{5}{|c|}{ Western region of Honshu Island } \\
\hline Asahi R. & 31 & 2011 & 0.707382 & \\
\hline Takahashi R. & 32 & 2011 & 0.707260 & \\
\hline Ashida R. & 33 & 2011 & 0.708759 & \\
\hline Nishiki R. & 34 & 2011 & 0.709272 & \\
\hline Hii R. & 35 & 2011 & 0.706260 & \\
\hline \multicolumn{5}{|l|}{ Shikoku Island } \\
\hline Yoshino R. & 36 & 2011 & 0.709045 & \\
\hline Nahari R. & 37 & 2011 & 0.711055 & \\
\hline Niyodo R. & 38 & 2011 & 0.709008 & \\
\hline Shimanto R. & 39 & 2011 & 0.708998 & \\
\hline
\end{tabular}


Table 2 (continued)

\begin{tabular}{|c|c|c|c|c|}
\hline Name of river & $\begin{array}{l}\text { Location } \\
\text { no. in Fig. } 1\end{array}$ & Sampling year & ${ }^{87} \mathrm{Sr} /{ }^{86} \mathrm{Sr}$ ratio & Reference \\
\hline \multicolumn{5}{|l|}{ Kyushu Island } \\
\hline Onga R. & 40 & 2011 & 0.706297 & \\
\hline Gokase R. & 41 & 2011 & 0.707509 & \\
\hline Hitotuse R. & 42 & 2011 & 0.712527 & \\
\hline Oyodo R. & 43 & 2011 & 0.707742 & \\
\hline Tenko R. & 44 & 2011 & 0.705710 & \\
\hline Sendai R. & 45 & 2011 & 0.706260 & \\
\hline Kuma R. & 46 & 2011 & 0.709581 & \\
\hline Chikugo R. & 47 & 2011 & 0.705469 & \\
\hline
\end{tabular}

${ }^{87} \mathrm{Sr} /{ }^{86} \mathrm{Sr}$ ratios of Chinese rivers (location nos. 1,2,3,5,6) and lake (location no. 4) are two-sample averages ${ }^{a}$ Errors are 2SD of multiple samples. Details are in the reference

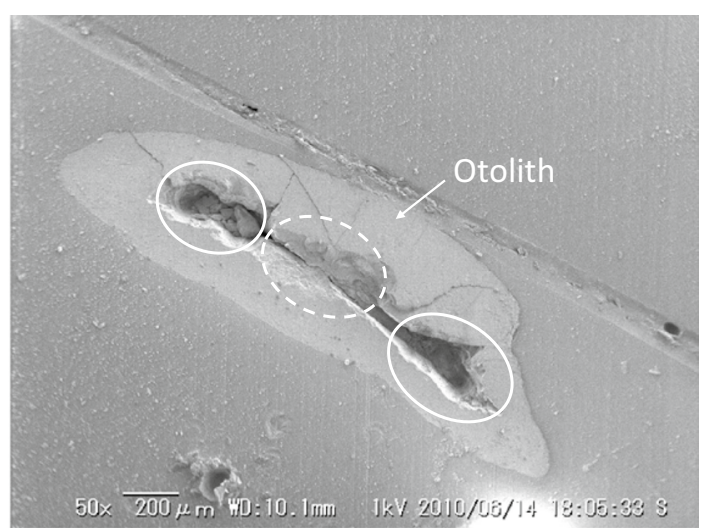

Fig. 2 Otolith section of a spawning-condition adult eel (no. U8-1) used for micromilling sampling and ${ }^{87} \mathrm{Sr} /{ }^{86} \mathrm{Sr}$ analysis. Solid and dashed circles indicate the portion sampled for analysis and the central portion drilled out so as to avoid contamination by the oceanic leptocephalus stage, respectively

of rivers in China, Korea, and Taiwan ranged between 0.710432 and 0.714101 (mean \pm SD: $0.711875 \pm 0.000848$ ), $0.713083-0.722798 \quad(0.716990 \pm 0.004290)$, and $0.711552-0.714691(0.713191 \pm 0.001425)$, respectively (Table 2). Whereas the aforementioned ratios were all $>0.71$, 22 out of 32 Japanese rivers had ${ }^{87} \mathrm{Sr} /{ }^{86} \mathrm{Sr}$ ratios $<0.71$, the overall range was between 0.705469 and 0.713091 $(0.708449 \pm 0.001999)$ (seven rivers in central Honshu Island, one in Shikoku Island, and two in Kyushu Island were characterized by ratios $>0.71$ ).

\section{Discussion}

The geology of East Asia is characterized by a greater age of bedrock formation in the continental region; the Chinese mainland (including the Korean Peninsula) comprising

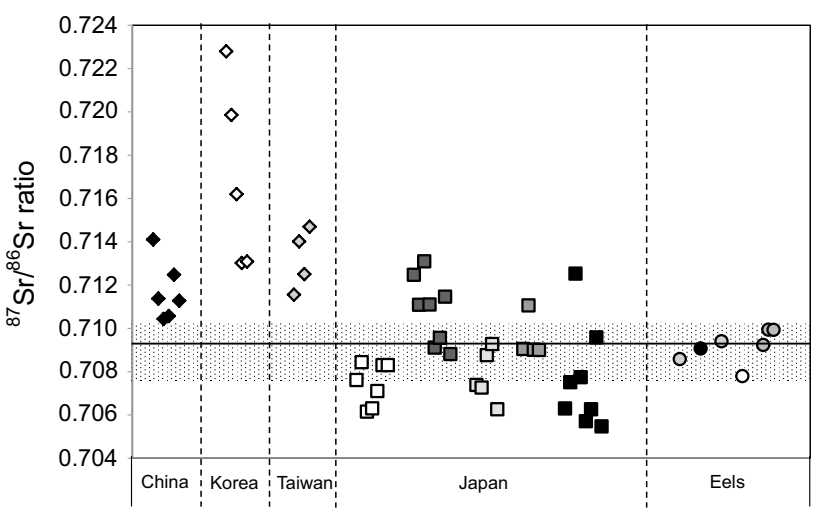

Fig. 3 Plots of the ${ }^{87} \mathrm{Sr} /{ }^{86} \mathrm{Sr}$ values of water samples from four regions of East Asia and of reproductive stage Japanese eels Anguilla japonica caught within the spawning area along the West Mariana Ridge in the western North Pacific. Samples are ordered in the same direction (left to right) as in Tables 1 and 2 (top to bottom). Shading indicates the general range of the eel values for comparison with the water samples. Bold line indicates the ${ }^{87} \mathrm{Sr} /{ }^{86} \mathrm{Sr}$ value of seawater. Japanese rivers are shown by six regions [north-eastern region (open triangle), central region (dark gray triangle), and western region (gray triangle) of Honshu Island, Shikoku Island (dark gray triangle), and Kyushu Island (filled triangle)]. White (circle), gray (circle) and black (circle) circles indicate "river", "estuarine", and "sea" eels, respectively

Precambrian continental block older than the Pacific Ocean margin and oceanic plate subduction-related orogenic belt, including the Japan archipelago and Taiwan Island (Teraoka and Okumura 2003, 2011). Figure 4 shows the East Asian framework, including Japan, Taiwan, China and the Korean Peninsula. Bedrocks of the main landmasses of Japan are primarily composed of Paleozoic to modern (543 million years ago-present) sedimentary, metamorphic and igneous rocks (Wakita 2013), where Northeastern Japan is characterized by post-Miocene volcanic and sedimentary rocks mostly covering a Paleozoic-Mesozoic basement of 
Fig. 4 Geological frameworks of Japan, Taiwan, China and the Korean Peninsula. Modified from Teraoka and Okumura (2003) and Li et al. (2014). NE Japan and SE Japan indicate Northeastern Japan and Southwestern Japan, respectively

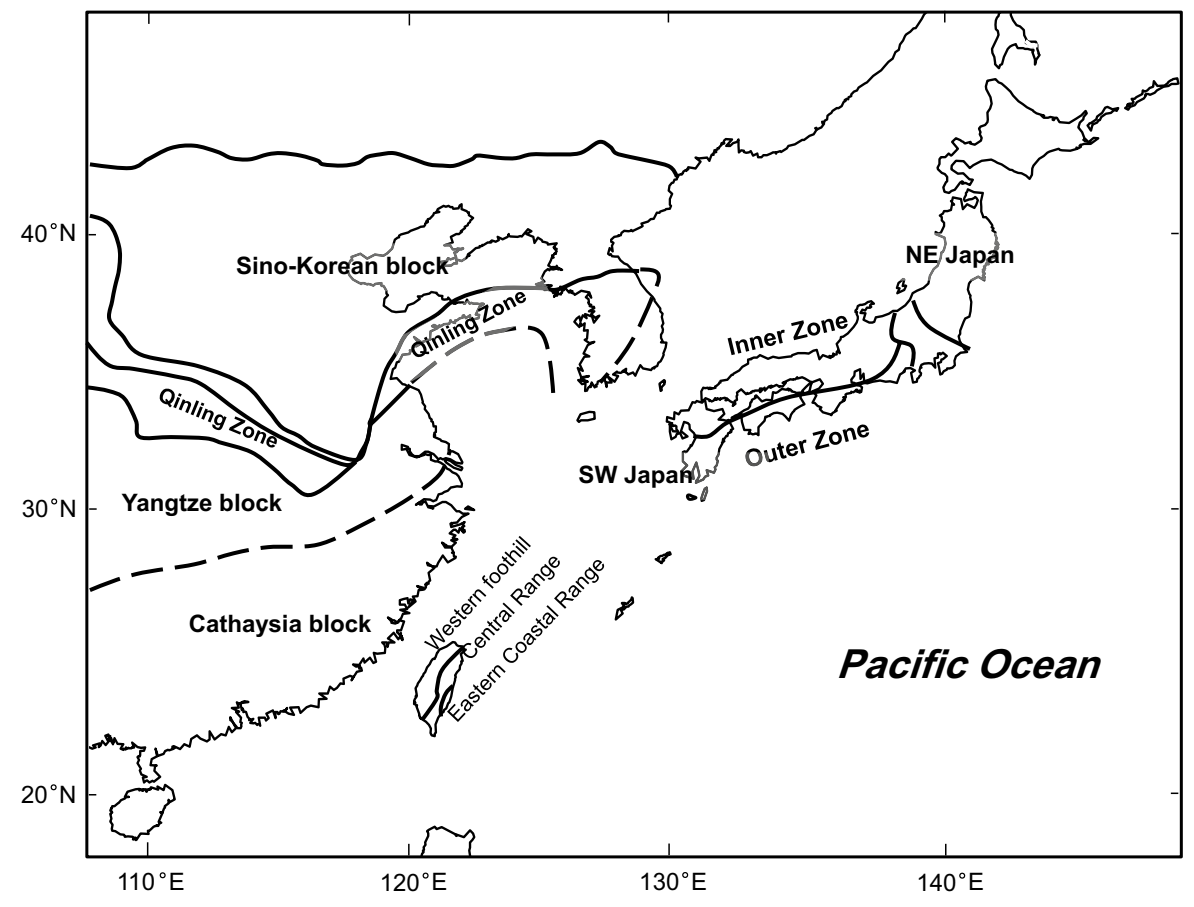

metamorphic/igneous rocks. Southwestern Japan is further divided into inner and outer zones by the Median Tectonic Line running through Kii Peninsula and Shikoku Island. The distribution of bedrock parallels the elongated direction of the archipelagic arc, with younger rock trending to the outer zone (Pacific side). The inner zone is composed of Paleozoic-Mesozoic granitic intrusive rocks with minor sedimentary rocks, whereas the outer zone comprises sedimentary/ metamorphic rocks of Mesozoic to Cenozoic age. Taiwan Island is characterized by three geological zones running approximately north-south: (1) Western foothills mostly comprising clastic rocks (Miocene-Quaternary), which originated from the Chinese mainland; (2) Central Range with clastic rocks (Eocene-Miocene) in the western region and metamorphic rock (Cretaceous) in the eastern region; and (3) Eastern Coastal Range, comprising post-Miocene clastic and volcanic rocks (Sibuet and Hsu 2004, Fig. 4). The Chinese mainland, as a whole, is covered by older bedrock (formed 2.4 billion-230 million years ago), primarily comprising three blocks: (1) Sino-Korean and Yangtze blocks, which are bordered by (2) the Qinling zone, running east-west in the central region; and (3) the Cathaysia block, expanding southeast of the Yangtze (Wang and Mo 1995; Zhao and Cawood 2012) (Fig. 4). The Sino-Korean block, including the middle-lower reaches of the Yellow River and North Korea, is composed of bedrocks dominated by Archean-early Proterozoic igneous and metamorphic rocks, and middle to later Proterozoic continental sedimentary rock. The Yangtze block, including the Yangtze valley and upper reaches, is composed of bedrocks dominated by
Late Archean-Early Protrozoic igneous and metamorphic rocks, and Late Proterozoic-Triassic oceanic sedimentary rock. The Cathaysia block bedrock is dominated by Archean igneous and metamorphic rocks, and Proterozoic-Silurian sedimentary rock (Li et al. 2014). Bedrock of the Korean Peninsula is primarily composed of metamorphic rocks, dominated by Precambrian gneiss, with Cretaceous-Cainozoic sedimentary rocks covering the southernmost part of the peninsula (Lee 1987), which are an eastward extension of the Sino-Korean block and Qinling zone. Detailed geological maps of East Asia, including Japan, are provided by Geological Survey of Japan, Advanced Institute of Science and Technology (https://gbank.gs.jp/geonavi/?lang=en).

The ${ }^{87} \mathrm{Sr} /{ }^{86} \mathrm{Sr}$ ratios of water samples from rivers examined in both the present and previous studies seemed to reflect some of the geological characteristics of each region of East Asia, as described above (Table 2). All of the river water samples from the Chinese mainland and Korean peninsula presented relatively high values $(>0.71)$, clearly higher than samples from most Japanese rivers (exceptions being rivers situated in central Honshu Island, over dominated by old Mesozoic sedimentary rocks). Although Han et al. (2010b) reported that river water from the Wujiang River, a southern Yangtze River tributary, had a ${ }^{87} \mathrm{Sr} /{ }^{86} \mathrm{Sr}$ ratio less than $0.71(0.7085)$, the present study indicated a ratio of 0.710432 for the lower river reach, almost consistent with the ratio of the Yangtze River mainstream (0.7098-0.7108) reported by Wang et al. (2007). Rivers along the western side of Taiwan, in which recruitment of Japanese eel was more abundant than on the eastern side of the island (Kuo 
1971), showed ${ }^{87} \mathrm{Sr} /{ }^{86} \mathrm{Sr}$ ratios greater than 0.71 , although the underlying geology was characterized by relatively new Miocene-Quaternary bedrock. However, Sano (2008) reported the chemical age of Monazites of the western foothills to be 230 million to 1850 million years, which is older than Japanese bedrock, by $\mathrm{U}-\mathrm{Pb}$ and $\mathrm{Pb}-\mathrm{Pb}$ aging methods.

The ${ }^{87} \mathrm{Sr} /{ }^{86} \mathrm{Sr}$ ratios of fish otoliths have been demonstrated as consistent with the ratio of ambient water in previous studies (Kennedy et al. 1997; 2000, 2002; BarnettJohnson et al. 2005; Hobbs et al. 2010; Amakawa et al. 2012; Garcez et al. 2015). Therefore, ${ }^{87} \mathrm{Sr} /{ }^{86} \mathrm{Sr}$ ratios of the otolith portion formed during the juvenile growth stage of the spawning-condition adult eels (one "river" and five "estuarine" eels) collected from the spawning area in 2008 and 2009 could be proxies for the ratios of their habitat waters. Based on a comparison of the ${ }^{87} \mathrm{Sr} /{ }^{86} \mathrm{Sr}$ ratios of the water samples from the four East Asian countries, the otolith ratio of the "river" eel (no. E16-2) was suggestive of a region in Japan, the closest matches being with northern, central, and southern Japanese rivers. The source of the "estuarine" eels was more complex to interpret, estuarine water being a mixture of sea water and river freshwater flowing into the estuary, such that ${ }^{87} \mathrm{Sr} /{ }^{86} \mathrm{Sr}$ ratio reflects the mixing rate of freshwater and seawater (e.g. Hobbs et al. 2010; Walther and Limburg 2012). Thus, when the ${ }^{87} \mathrm{Sr} /{ }^{86} \mathrm{Sr}$ ratio of estuarine water (= the otolith ratio of an estuarine eel) is less than the seawater ratio of 0.7092 (Goldstein and Jacobsen 1987; McArthur 1994), that of the river water flowing into the estuary must be even lower. Conversely, the river water ratio must be higher than the actual estuarine water ratio when the latter is greater than 0.7092 . This suggests that the ${ }^{87} \mathrm{Sr} /{ }^{86} \mathrm{Sr}$ ratios of the river which eel no. U8-1("estuarine" eel) inhabited during the juvenile growth stage was even lower than the otolith ratios (0.708580), and such lower ratio was found only from Japanese rivers. The water ratios of rivers flowing into the estuarine habitats of eel numbers E18-1, M1, EH13-1 and M3 must have been higher than their respective otolith ratios $(0.709404,0.709231,0.709928$ and 0.709935$)$. This indicates that those eels may have been from estuarine or coastal waters, depending on the percentage contribution of river freshwater to their otolith ratio values, although the possibility of their having come from Japan cannot be excluded. However, for them to have come from Korea or Taiwan requires them to have lived in high-salinity areas. The "sea" eel (no. U8-2) with the otolith ${ }^{87} \mathrm{Sr} /{ }^{86} \mathrm{Sr}$ ratio (0.709068) slightly lower than the sea water ratio may have also come from Japanese coastal waters, since the ${ }^{87} \mathrm{Sr} /{ }^{86} \mathrm{Sr}$ ratio of the latter appears to have been strongly affected by river freshwater with even lower ratios. Because at least two spawning-condition eels (no. E16-2 and U8-1), possibly in addition to the "sea" eel with the lower ${ }^{87} \mathrm{Sr} /{ }^{86} \mathrm{Sr}$ ratio (no. U8-2) spent their juvenile growth phase in Japan, rivers and estuaries in Japan may be highly important for reproduction and population stability of the species. It also indicates the significance of management and restoration of Japanese eels in Japan. Growth areas of the other eels that had otolith ${ }^{87} \mathrm{Sr} /{ }^{86} \mathrm{Sr}$ ratios of greater than 0.71 could not be determined here; further information, including otolith elemental and isotope compositions, is necessary. A. japonica has been recorded from the northeastern region of Luzon Island (Cagayan Estuary), Philippine (Tabeta et al. 1975). Basement of Cagayan basin is of Oligocene igneous and sedimentary rocks covered with fossiliferous limestone and shale (Suzuki 1989; Florendo 1994). Basement of Ilocos region (northwestern region of Luzon Island) including Cordillera-Central mountains is characterized by late Eocene sedimentary rocks. Granite from northern region of Luzon Island was radiometrically aged in Cretaceous to Paleocene. As such, northern region of Luzon Island is composed of young bedrock, suggesting that $A$. japonica from there may have low otolith ${ }^{87} \mathrm{Sr} /{ }^{86} \mathrm{Sr}$ ratio similar to those from Japan. However, population size of $A$. japonica in northern region of Luzon Island is quite small because $A$. japonica elvers occurred in limited months (January and February) in Cagayan Estuary with constitution of only 1-2\% in sympatric eel elvers (A. marmorata and A. bicolor pacifica) (Tabeta et al. 1975). This suggests a low contribution of $A$. japonica inhabiting northern region of Luzon Island to reproductive population in the spawning area. The possibility that they were included in the spawning-condition adults examined in the present study seemed to be low.

The stock collapse of anguillid species in the Northern Hemisphere is thought to be caused at least in part, by various anthropogenic factors (Feunteun 2002; Tatsukawa 2003; Dekker 2003; Tsukamoto et al. 2009; Itakura et al. 2014, 2015; Yokouchi et al. 2008, 2014). Tatsukawa (2003) suggested dam construction as a major factor for the decline in Japanese eel distribution in Japan, as has occurred in other countries. Chen et al. (2014) also documented eel habitat loss in various areas in East Asia, which would have reduced the number of silver eels produced each year, and Itakura et al. (2014, 2015) presented data showing the negative effects of revetment shorelines in rivers on eel growth habitats. On the other hand, various attempts, such as (1) regulations of glass, yellow and silver eel fisheries, (2) management of migration obstacles (chemical or physical), in particular fish passes, and (3) restocking, have been conducted to manage and restore local stocks of Japanese eels, as has been done for European eel stocks (Moriarty and Dekker 1997; Knights and White 1998; Feunteun 2002; McCarthy et al. 2014; Brämick et al. 2016). Furthermore, monitoring of glass eel recruitment all year-round has been started on several rivers in each East Asian country (Japan, Taiwan, China and Korea) with an attempt to make those rivers sanctuaries or model rivers in near future (Kuroki et al. 2014). Because juvenile eels initially accumulate in upper estuaries 
and then disperse either in upstream or downstream as they grow (Kaifu et al. 2010), the growth condition in estuarine water just after recruitment appear to determine the direction of subsequent movement (Wakiya et al. 2016). It has been suggested that eels "evaluate" the alternatives of "downstream residency" or "upstream emigration" in accordance with the strategy most likely increasing individual fitness. Therefore, it is important to adequately manage the entire river system from the lower estuary to upper reaches, thus allowing eel movement in either direction (Wakiya et al. 2016). Furthermore, the demographic heterogeneity among the river systems supporting Japanese eels, pointed to the importance of conserving a variety of habitats in multiple river systems as an inclusive management target, in addition to restoration of habitat diversity of within single river systems (Yokouchi et al. 2008; 2014).

In the present study, two ("river" and "estuarine" eels) of seven spawning-condition adults collected from the spawning area near the Mariana Trench were suggested to have inhabited Japanese rivers and/or estuaries based on ${ }^{87} \mathrm{Sr} /{ }^{86} \mathrm{Sr}$ analyses of their otoliths and water samples from rivers of East Asian countries (China, Korea, Taiwan and Japan). This supports the likely significance of various management and restoration efforts for Japanese eel in Japanese archipelago.

Acknowledgements We thank the captains and crews of R/V Kaiyo Maru and Hokko Maru for their assistance in adult Japanese eel sampling, and M.J. Miller and G. Hardy for helping to improve the manuscript. This study was supported in part by JSPS KAKENHI Grant number $21380122,15 \mathrm{H} 04543$ and 24380105 to TO, and number JP26450268, 26252030, 17K19300 to KT, and by JST CREST Grant number JPMJCR13A3, JPMJCR13A4. This study followed the animal experimental use guidelines of the University of Tokyo.

Open Access This article is distributed under the terms of the Creative Commons Attribution 4.0 International License (http://creativeco mmons.org/licenses/by/4.0/), which permits unrestricted use, distribution, and reproduction in any medium, provided you give appropriate credit to the original author(s) and the source, provide a link to the Creative Commons license, and indicate if changes were made.

\section{References}

Aarestrup K, Økland F, Hansen MM, Righton D, Gargan P, Castonguay M, Bernatchez L, Howey P, Sparholt H, Pedersen M, Mckinley RS (2009) Oceanic spawning migration of the European eel (Anguilla anguilla). Science 325:1660

Amakawa H, Suzuki T, Takahashi T, Tatsumi Y, Otake T (2012) Sr isotopic compositions of ayu otolith and its ambient water. Fish Sci 78:1023-1029

Amano Y, Kuwahara M, Takahashi T, Shirai K, Yamane K, Amakawa H, Otake T (2013) Otolith elemental and Sr isotopic composition as a natal tag for Biwa salmon Onchorhynchus masou subsp, in Lake Biwa, Japan. Aquat Biol 19:85-95
Aoyama J, Watanabe S, Miller MJ, Mochioka N, Otake T, Yoshinaga $\mathrm{T}$, Tsukamoto K (2014) Spawning sites of the Japanese eel in relation to Oceanographic structure and the West Mariana Ridge. PLoS One 9:e88759

Barnett-Johnson R, Ramos FC, Grimes CB, MacFariane RB (2005) Validation of $\mathrm{Sr}$ isotopes in otoliths by laser ablation multicollector inductively coupled plasma mass spectrometry (LA-MCICPMS): opening avenues in fisheries science applications. Can J Fish Aquat Sci 62:2425-2430

Beguer-Pon M, Castonguay M, Shan S, Benchetrit J, Dodson JJ (2015) Direct observations of American eels migrating across the continental shelf to the Sargasso Sea. Nat Commun 6:8. https://doi. org/10.1038/ncomms 9705

Bonhommeau S, Chassot E, Planque B, Rivot E, Knap AH, Le Pape O (2008) Impact of climate on eel populations of Northern Hemisphere. Mar Ecol Prog Ser 373:71-80

Brämick U, Fladung E, Simon J (2016) Stocking in essential to meet the silver eel escapement target in a river system with currently low natural recruitment. ICES J Mar Sci 73:91-100

Chang YL, Sheng J, Ohashi K, Beguer-Pon M, Miyazawa Y (2015) Impacts of interannual ocean circulation variability on Japanese eel larval migration in the western North Pacific Ocean. PLoS One 10:e144423

Chang YL, Miyazawa Y, Beguer-Pon M (2016) Simulating the oceanic migration of silver Japanese eel. PLoS One. https://doi. org/10.1371/journal.pone.0150187

Chen J-Z, Huang S-L, Han Y-S (2014) Impact of long-term habitat loss on the Japanese eel Anguilla japonica. Estuar Coast Shelf Sci 151:361-369

Chow S, Kurogi H, Mochioka N, Kaji S, Okazaki M, Tsukamoto K (2009) Discovery of mature freshwater eels in the open ocean. Fish Sci 75:257-259

Chow S, Kurogi H, Katayama S, Ambe D, Okazaki M, Watanabe T, Ichikawa T, Kodama M, Aoyama J, Shinoda A, Watanabe S, Tsukamoto K, Miyazaki S, Kimura S, Yamada Y, Nomura K, Tanaka H, Kazeto Y, Hata K, Handa T, Tawa A, Mochioka N (2010) Japanese eel (Anguilla japonica) do not assimilate nutrition during the oceanic reproductive migration: evidence from stable isotope analysis. Mar Ecol Prog Ser 402:233-238

Chow S, Okazaki M, Watanabe T, Segawa K, Yamamoto T, Kurogi H, Tanaka H, Ai K, Kawai M, Yamamoto S, Mochioka N, Manabe R, Miyake Y (2015) Light-sensitive vertical migration of the Japanese eel Anguilla japonica revealed by realtime tracking and its utilization for geolocation. PLoS One 10:e0121801. https://doi.org/10.1371/journal.pone.0121801

Dekker W (2003) On the distribution of the European eel (Anguilla anguilla) and its fisheries. Can J Fish Aquat Sci 60:787-799

Feunteun E (2002) Management and restoration of European eel population (Anguilla anguilla): an impossible bargain. Ecol Eng 18:575-591

Florendo FF (1994) Tertiary arc rifting in northern Luzon, Philippines. Tectonics 13:623-640

Friedland KD, Miller MJ, Knights B (2007) Oceanic changes in the Sargasso Sea and declines in recruitment of the European eel. ICES J Mar Sci 64:519-530

Garcez RCS, Humston R, Harbor D, Freitas CES (2015) Otolith geochemistry in young-of-the-year peacock bass Cichla temensis for investigating natal dispersal in the Rio Negro (AmazonBrazil) river system. Ecol Freshw Fish 24:242-251

Goldstein SJ, Jacobsen SB (1987) The Nd and Sr isotopic systematics of river-water dissolved material: implications for the sources of Nd and $\mathrm{Sr}$ in seawater. Chem Geol 66:245-272

Gong XL, Ren SJ, Cui ZK, Yue LJ (2014) Genetic evidence for panmixia of Japanese eel (Anguilla Japonica) populations in China. Gen Mol Res 13:768-781 
Han G, Tang Y, Xu Z (2010a) Fluvial geochemistry of rivers draining karast terrain in Southwest China. J Asian Earth Sci 38:65-75

Han YS, Hung CL, Tzeng WN (2010b) Population genetic structure of the Japanese eel Anguilla japonica: panmixia at spatial and temporal scales. Mar Ecol Prog Ser 401:221-253

Hobbs JA, Lewis LS, Ikemiyagi N, Sommer T, Baxter RD (2010) The use of otolith strontium isotopes $\left({ }^{87} \mathrm{Sr} /{ }^{86} \mathrm{Sr}\right)$ to identify nursery habitat for a threatened estuarine fish. Environ Biol Fish 89:557-569

Ishikawa S, Tsukamoto K, Nishida M (2001) Characterization of microsatellite loci from the Japanese eel Anguilla japonica. Mol Ecol Notes 1:140-142

Itakura H, Kitagawa T, Miller MJ, Kimura S (2014) Declines in catches of Japanese eels in rivers and lakes across Japan: have river and lake modifications reduced fishery catches? Landsc Ecol Eng 11:147-160

Itakura H, Kaino T, Miyake Y, Kitagawa T, Kimura S (2015) Feeding, condition, and abundance of Japanese eels from natural and revetment habitats in the Tone River, Japan. Environ Biol Fish 98:1871-1888

Jacoby D, Gollock M (2014) Anguilla japonica. The IUCN Red list of threatened species. Version 2014-3. http://www.iucnredlist.org

Jacoby D, Casselman J, DeLucia M, Hammerson GA, Gollock M (2014) Anguilla rostrata. The IUCN Red list of threatened species. Version 2014-3. http://www.iucnredlist.org

Jellyman D, Tsukamoto K (2002) First use of archival transmitters to track migrating freshwater eels Anguilla dieffenbachii at sea. Mar Ecol Prog Ser 233:207-215

Jellyman D, Tsukamoto K (2005) Swimming depths of off-shore migrating longfin eels Anguilla dieffenbachii at sea. Mar Ecol Prog Ser 286:261-267

Jellyman D, Tsukamoto K (2010) Vertical migrations may control maturation in migrating female Anguilla dieffenbachii. Mar Ecol Prog Ser 404:241-247

Kaifu K, Tamura M, Aoyama J, Tsukamoto K (2010) Dispersal of yellow phase Japanese eels Anguilla japonica after recruitment in the Kojima Bay-Asahi River system, Japan. Environ Biol Fish 52:253-261

Kennedy BP, Folt CL, Blum JD, Chamberlain CP (1997) Natural isotope markers in salmon. Nature (Lond.) 387:766-767

Kennedy BP, Blum JD, Folt CL, Nislow KH (2000) Using natural strontium isotopic signatures as fish markers: methodology and application. Can J Fish Aquat Sci 57:2280-2292

Kennedy BP, Klaue A, Blum JD, Folt CL, Nislow KH (2002) Reconstructing the lives of fish using Sr isotopes in otoliths. Can J Fish Aquat Sci 59:925-929

Kim H, Kimura S, Shinoda A, Kitagawa T, Sasai Y, Sasaki H (2007) Effect of El Nino on migration of the Japanese eel (Anguilla japonica). ICES J Mar Sci 64:1387-1395

Kimura S, Tsukamoto K (2006) The salinity front in the North Equatorial Current: a landmark for the spawning migration of the Japanese eel (Anguilla japonica) related to the stock recruitment. Deep-Sea Res II 53:315-325

Knights B, White E (1998) Enhancing immigration and recruitment of eels: the use of passes and associated trapping systems. Fisheries Manag Ecol 5:459-471

Kuo H (1971) Approach of eel elvers to the land in Taiwan. Aquaculture (Yoshoku) 1:52-56

Kurogi H, Okazaki M, Mochioka N, Jinbo T, Hashimoto H, Takahashi M, Tawa A, Aoyama J, Shinoda A, Tsukamoto K, Tanaka H, Gen K, Kazeto Y, Chow S (2011) First capture of post-spawning female of the Japanese eel Anguilla japonica at the southern West Mariana Ridge. Fish Sci 77:199-205

Kuroki M, Righton D, Walker AM (2014) The importance of Anguillids: a cultural and historical perspective introducing papers from the World Fisheries Congress. Ecol Freshw Fish 23:2-6
Lee DS (1987) Geology of Korea. Kyohak-Sa, Seoul

Li J, Zhang Y, Dong S, Johnston ST (2014) Cretaceous tectonic evolution of South China: a preliminary synthesis. Earth Sci Rev 134:98-136

Manabe R, Aoyama J, Watanabe K, Kawai M, Miller MJ, Tsukamoto K (2011) First observations of the oceanic migration of Japanese eel, from pop-up archival transmitting tags. Mar Ecol Prog Ser 437:229-240

McArthur JM (1994) Recent trends in strontium isotope stratigraphy. Tera Rev 6:331-358

McCarthy TK, Nowak D, Grennan J, Bateman A, Conneely B, MacNamara R (2014) Spawner escapement of European eel (Anguilla anguilla) from the river Erne, Irland. Ecol Freshw Fish 23:21-32

Miller MJ, Kimura S, Friedland KD, Knights B, Kim H, Jellyman DJ, Tsukamoto K (2009) Review of ocean-atmospheric factors in the Atlantic and Pacific oceans influencing spawning and recruitment of anguillid eels. In: Haro A, Avery T, Beal K, Cooper J, Cunjak R, Dadswell M, Klauda R, Moffitt C, Rulifson R, Smith $\mathrm{K}$ (eds) Challenges for diadromous fishes in a dynamic global environment. American Fisheries Society Symposium Publication, Bethesda, pp 231-249

Minegishi Y, Aoyama J, Yoshinaga N, Tsukamoto K (2012) Lack of genetic heterogeneity in the Japanese eel based on a spatiotemporal sampling. Coast Mar Sci 35:269-276

Mochioka N, Wakiya R, Kurogi H, Chow S, Morishita K, Aoyama J, Tsukamoto K (2010) Environmental histories of adult eels collected from the spawning ground in 2008 and 2009. Abstracts, the Japanese Society of Fisheries Science Autumn Meeting 2009. p 17 (in Japanese)

Molly L, Wynne P, Wilson KA, Limbutg KE (2015) Retrospective examination of habitat use by blueback herring (Alosa aestivalis) using otolith microchemical methods. Can J Fish Aquat Sci 72:1073-1086

Moriarty C, Dekker W (1997) Management of European eel fisheries. Irish Fish Bull 15:108

Righton D, Westerberg H, Feunteun E, Økland F, Gargan P, Amilhat E, Metcalfe J, Lobon-Cervia J, Sjöberg N, Simon J, Acou A, Vedor M, Walker A, Trancart T, Brämick U, Aarestrup K (2016) Empirical observations of the spawning migration of European eels: the long and dangerous road to the Sargasso Sea. Science Advances 2:e1501694

Rooker JR, Secor DH, Matrio GD, Schloesser R, Block BA, Neilson JD (2008) Natal homing and connectivity in Atlantic bluefin tuna population. Science 322:742-744

Rooker JR, Arrizabalaga H, Fraile I, Secor DH, Dettman DL, Abid N, Addis P, Deguara S, Karakulak FS, Kimoto A (2014) Crossing the line: migratory and homing behaviors of Atlantic bluefin tuna. Mar Ecol Prog Ser 504:265-276

Sano Y (2008) Lead and Strontium stable isotope measurements by using a high lateral resolution secondary ion mass spectrometer (NanoSIMS). Radioisotopes 57:579-591 (in Japanese with English abstract)

Sano Y, Shirai K, Takahata N, Amakawa H, Otake T (2008) Ion microprobe $\mathrm{Sr}$ isotope analysis of carbonates with about $5 \mu \mathrm{m}$ spatial resolution: an example from an ayu otolith. Appl Geochem 23:2406-2413

Schabetsberger R, Økland F, Kalfatak D, Sichrowsky U, Tambets M, Aarestrup K, Gubili C, Sarginson J, Boufana B, Jehle R, Dall'Olmo G, Miller MJ, Scheck A, Kaiser R, Quartly G (2015) Genetic and migratory evidence for sympatric spawning of tropical Pacific eels from Vanuatu. Mar Ecol Prog Ser 521:171-187

Sibuet J-C, Hsu S-K (2004) How was Taiwan created? Tectonophysics 379:159-181

Suzuki Y (1989) A tectonic evolution of Philippine Islands. Chisitsu News 413:16-29 (in Japanese) 
Tabeta O, Takai T, Matsui I (1975) Record of the Japanese eel from the Philippines. Bull Jpn Soc Sci Fish 41:641-644

Takahashi T, Yoshikawa M, Shibata T, Tatsumi Y, Shimizu N (2006) $\mathrm{Sr}$ isotopic micro-analyses of plagioclase in andesites from Zao volcano, NE Japan. Frontier Res Earth Evol 2:1-5

Takahashi T, Hirahara Y, Miyazaki T, Vaglarov BS, Chang Q, Kimura J, Tatsumi Y (2009) Precise determination of Sr isotope ratios in igneous rock samples and application to micro-analysis of plagioclase phenocrysts. JAMSTEC Rep Res Dev SI:59-64

Tanaka E (2014) Stock assessment of Japanese eels using Japanese abundance indices. Fish Sci 80:1129-1144

Tatsukawa K (2003) Eel resources in East Asia. In: Aida K, Tsukamoto K, Yamauchi K (eds) Eel biology. Springer, Tokyo, pp 293-298

Teraoka Y, Okumura K (2003) Geological map of East Asia, scale 1:3,000,000. Geological Service of Japan, AIST, Tokyo

Teraoka Y, Okumura K (2011) Geological map of East Asia, scale 1:5,000,000. Geological Service of Japan, AIST, Tokyo

Thorrold SR, Latkoczy C, Swart PK, Jones CM (2001) Natal homing in marine fish metapopulation. Science 291:297-299

Tseng MC, Chen CA, Kao HW, Tzeng WN, Lee SC (2001) Polymorphisms of GA/GT microsatellite loci from Anguilla japonica. Mar Biotechnol 3:275-280

Tsukamoto K, Arai T (2001) Facultative catadromy of the eel Anguilla japonica between freshwater and seawater habitats. Mar Ecol Prog Ser 220:265-276

Tsukamoto K, Nakai I, Tesch FW (1998) Do all freshwater eels migrate? Nature 396:635-636

Tsukamoto K, Aoyama J, Miller MJ (2009) Status of the Japanese eel: resources and recent research. In: Casslman JM, Cairns DK (eds) Eels at the edge: science, status, and conservation concerns. American Fisheries Society, Symposium 58 Bethesda, Maryland, pp 21-35

Tsukamoto K, Chow S, Otake T, Kurogi H, Mochioka N, Miller MJ, Aoyama J, Kimura S, Watanabe S, Yoshinaga T, Shinoda A, Kuroki M, Oya M, Watanabe T, Hata K, Ijiri S, Kazeto Y, Nomura K, Tanaka H (2011) Oceanic spawning ecology of freshwater eels in the western North Pacific. Nat Commun 2:179. https ://doi.org/10.1038/ncomms1174
Tzeng WN, Wang CH, Wickström H, Reizenstein M (2000) Occurrence of the semi-catadromous European eel Anguilla anguilla in the Baltic Sea. Mar Biol 137:93-98

Wakita K (2013) Geology and tectonics of Japanese island: a reviewthe key to understanding the geology of Asia. J Asian Earth Sci 72:75-87

Wakiya R, Kaifu K, Mochioka N (2016) Growth conditions after recruitment determine residence-emigration tactics of female Japanese eels Anguilla japonica. Fish Sci 82:729-736

Walther SD, Limburg KE (2012) The use of otolith chemistry to characterize diadromous migrations. J Fish Biol 81:796-825

Walther BD, Dempster T, Letnic M, McCulloch MT (2011) Movements of diadromouos fish in large unregulated tropical rivers inferred from geochemical tracers. PLoS One 6:e18351

Wang HZ, Mo XX (1995) An outline of the tectonic evolution of China. Episodes 18:6-16

Wang ZL, Zhang J, Liu CQ (2007) Strontium isotopic compositions of dissolved and suspended loads from the main channel of the Yangtze River. Chemosphere 69:1081-1088

Yamanaka M, Nakano T, Tase N (2005) Hydrogeochemical evolution of confined groundwater in northeastern Osaka Basin, Japan: estimation of confined groundwater flux based on a cation exchange mass balance method. Appl Geochem 20:295-316

Yokouchi K, Aoyama J, Oka HP, Tsukamoto K (2008) Variation in the demographic characteristics of yellow-phase Japanese eels in different habitats of the Hamana Lake system, Japan. Ecol Freshw Fish 17:639-652

Yokouchi K, Kaneko Y, Kaifu K, Aoyama J, Uchida K, Tsukamoto K (2014) Demographic survey of the yellow-phase Japanese eel Anguilla japonica in Japan. Fish Sci 80:543-554

Zhao G, Cawood PA (2012) Precambrian geology of China. Precambrian Res 222-223:13-54

Publisher's Note Springer Nature remains neutral with regard to jurisdictional claims in published maps and institutional affiliations. 